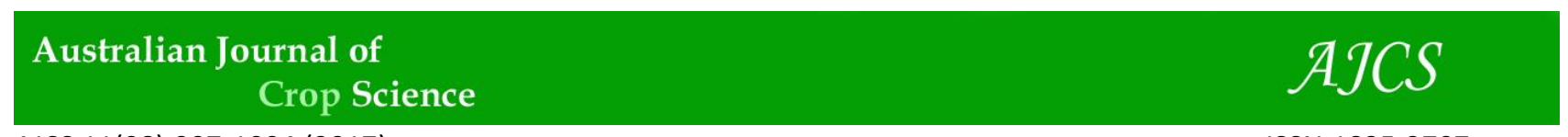

AJCS 11(08):997-1004 (2017)

ISSN:1835-2707

doi: 10.21475/ajcs.17.11.08.pne500

\title{
Impact of heat stress on Fusarium wilt $(F$. solani) incidence in cultivated tomato and related species
}

\author{
Muhammed Alsamir ${ }^{1,2 *}$, Nabil. M. Ahmad ${ }^{1}$, Tariq Mahmood ${ }^{1}$, Richard Trethowan $^{1}$ \\ ${ }^{1}$ Plant Breeding Institute, Faculty of Agriculture and Environment, University of Sydney, Cobbitty, NSW 2570, \\ Australia \\ ${ }^{2}$ The Date Palm Research Center, University of Basrah, Basrah, Iraq
}

*Corresponding author: alsamir.hameed@sydney.edu.au; malsamir@ hotmail.com

\begin{abstract}
The incidence of Fusarium wilt on tomato is increasing with rising global temperatures. To assess the impact of this disease, a factorial experiment of ten tomato genotypes grown at two temperatures and two levels of disease severity was established using hydroponics in a poly tunnel house. Fusarium wilt inoculum was used to promote disease and the heat treatment produced temperatures $>40^{\circ} \mathrm{C}$ for most of the growing season. Genotypes varied significantly for disease incidence and response to heat stress. Significant temperature $\mathrm{x}$ disease treatment interactions were observed for number of inflorescences per plant (IPP), fruit set ratio (FSR), number of fruits per plant (FPP), fresh fruit weight (FFW), plant dry weight (PDW) and disease severity index (DSI). A highly significant correlation $\left(\mathrm{R}^{2}=0.98\right)$ was observed between disease incidence under both control and high-temperature treatments, even though the treatments were significantly different. Biomass was reduced under both heat and disease stress and was correlated across treatments $\left(\mathrm{R}^{2}=0.86\right)$. The genotype LA3847, characterized by relatively low fruit set inhibition and high fruit yield, was classified as tolerant to both heat and disease stress. Concurrent selection for improved disease and heat tolerance appears possible as the disease severity index and the heat stress response were not correlated $\left(R^{2}=0.11\right)$.
\end{abstract}

Keywords: tomato, genetic variability, heat stress, Fusarium wilt.

Abbreviations: IPP_number of inflorescence per plant; DSI_ disease severity index; FSR_ fruit set ratio; FPP_ fruit per plant; FFW_ fresh fruit weight; PDW_ plant dry weight.

\section{Introduction}

Tomato is a member of the Solanaceae family and an important horticultural crop cultivated both under field and greenhouse conditions. It originated from the wild ancestor Lycopersicon esculentum cerasiforme (syn.: Solanum lycopersicum cerasiforme) and was domesticated in the Andean region of South America and in Mexico (Bai and Lindhout, 2007). Although tomato plants can grow under a wide range of climatic conditions, optimal fruit set and fruit weight are limited to a much narrower temperature range. Fruit set is interrupted when day/night temperatures exceed $26^{\circ} \mathrm{C} / 20^{\circ} \mathrm{C}$ and yield is subsequently reduced (Lohar and Peat, 1998). Heat tolerance in tomato was defined as "the ability to set fruits under night temperatures not lower than $21^{\circ} \mathrm{C}$ " (Villareal et al., 1978). Kinet and Peet, (1997) reported the effects of high temperature on plant reproduction. These impacts were greatest on: (1) meiosis in the pollen and ovule mother cells; (2) stigma position; (3) development of the androecium and the anther (resulting in reduced dehiscence and pollen shed); (4) the number of pollen grains retained by the stigma; (5) pollen germination; (6) pollen tube growth; (7) ovule viability; (8) fertilization and post fertilization processes; and (9) growth of the endosperm, pre-embryo and fertilized embryo. Plants are exposed to a variety of stresses during their life cycle and many species have developed defense mechanisms to cope with stress including the accumulation of compatible solutes such as polyols, sugars, amino acids and betaines (Rhodes and Hanson, 1993). The accumulation of these solutes enables survival under stressed conditions (Bohnert et al., 1995; Chen and Murata, 2002).

Tomato was introduced to Europe in the 16th century and quickly spread through the Mediterranean region (EsquinasAlcazar, 1981; Pék and Helyes, 2004). Thousands of tomato cultivars have since been developed through breeding and selection. Tomato breeding can be broadly divided into four historical phases: (1) breeding for yield in the 1970s, (2) breeding for disease resistance, (3) breeding for long shelflife in the 1980s, and (4) breeding for nutritional quality and taste in the 1990s and beyond. Breeding programs have produced unique varieties such as the dwarf 'Micro-Tom' released in 1989 and the first transgenic tomato 'FlavrSavr' released in 1994. Evaluation of the chemical and nutritional quality of fresh tomatoes is essential if new cultivars that satisfy market needs are to be developed. These characteristics must also be stable under high-temperature stress given climate change predictions. Unlike the wild $L$. chilense, the heat tolerance and adaptation of commercial tomatoes is limited to specific environments and heat stress has only recently been recognized as a serious problem worldwide (Sato et al., 2000; Peet et al., 1997; Hedhly, 2009). Fruit number, fruit weight and seed number per fruit can be significantly reduced in tomatoes when daily mean temperatures are raised from 25 to $29^{\circ} \mathrm{C}$ (Peet et al., 1998). Increasing temperatures have increased disease incidence in tomato (Singh and Kamal, 2012). Tomato plants are infected by several soil borne fungal pathogens that cause root rot and 
wilt including Fusarium spp., Rhizoctonia solani, and Sclerotium rolfsii (Bogner et al., 2016, Saseetharan et al., 2014, Abu Bakar et al., 2013, Abdel-Monaim, 2012 and Saad, 2006). These root diseases reduce both crop yield and quality. Fusarium is a cosmopolitan genus of filamentous ascomycete fungi (Sordariomycetes: Hypocreales: Nectriaceae) that include many toxin-producing plant pathogens of agricultural importance. Fusarium diseases include wilts, blights, rots and cankers of many horticultural, field, ornamental and forest crops in both agricultural and natural ecosystems. Fusarium also produces a diverse array of toxic secondary metabolites (mycotoxins) such as trichothecenes and fumonisins that can contaminate agricultural products, making them unsuitable for food or feed (Woloshuk and Shim, 2013). Fusarium is geographically widespread and responsible for most of the production losses in tomato worldwide. However, the interaction between temperature and Fusarium disease aggressiveness on tomato is not well understood (Robert et al., 2002).

Fungicides are generally used to control Fusarium; however these chemicals can be hazardous to human health and the environment. There is a need to discover and apply more environmentally sustainable control methods (Rojo et al., 2007).

Fusarium solani is distinguished from other Fusarium spp. based on a number of morphological features (Leslie and Summerell, 2006). The most important of these are the growth conditions in culture (Matuo and Snyder, 1973), the appearance of chlamydospores and long monophialides and macroconidia; although the macroconidia can be variable in size depending on geographical origin (Burgess et al., 1994). The relationship between high temperature and Fusarium wilt incidence has been studied in other crops (Tu 1994, Scott et al., 2010, Fang et al., 2011). However, little is known about these interactions in tomato. This study aimed to evaluate: 1) the effect of high temperature on Fusarium wilt incidence in tomato, and 2) genotypic responses to disease pressure under high temperature.

\section{Results}

Significant differences were observed among genotypes and between disease and heat treatments for various traits including number of inflorescences per plant (IPP), fresh fruit weight (FFW), number of fruits per plant (FPP), fruit set ratio (FSR), plant dry weight (PDW) and the disease susceptibility index (DSI) under combined disease and heat stress (Table 1).

\section{Trait means}

All genotype and treatment main effects were significant as were all two-way interactions with the exception of genotype $\mathrm{x}$ temperature for DSI (Table 1). The three-way interactions were also mostly significant with the exception of genotype $x$ disease $\mathrm{x}$ temperature indicating a complex genotype response to the combined stresses.

\section{Number of Inflorescences per plant (IPP)}

IPP scores ranged from 77 to 2.66 depending on the genotype and stress treatment (Table 1). The highest IPP scores in heat, disease and heat and disease (heat + disease) stress treatments were observed for the genotypes LA1930 (S. chilense) and LA0373 (S. pimpinellifolium). Low scores were noted for LA0716 (S. pennelli) under heat stress and LA4252 under disease and heat + disease stress.
A rank change among genotypes was observed to some degree as the genotype $\mathrm{x}$ disease interaction was significant.

\section{Fruit set inhibition}

The highest inhibition of fruit set under heat, disease and heat + disease stress was observed for LA4252 and Jagour (Table 2). The genotypes Bush Beef Steak and LA3847 showed the lowest inhibition of fruit set under all three stress regimes.

\section{Disease severity index}

The highest disease severity under normal temperatures was observed for LA4252 and Jagour (Table 2). However, when disease and heat stress were combined the genotype Jagour remained highly susceptible and Bush Beef Steak surpassed LA4252 in disease severity. The wild species were generally more resistant and LA0373 and LA1930 showed low severity in both temperature treatments.

The DSI under control and under heat stress treatments were positively and significantly correlated $\left(\mathrm{R}^{2}=0.983\right)$ (Fig. 2).

\section{Plant dry weight}

The highest plant dry weight across the control, heat and disease stress treatments was observed for VI005856 and LA1930 (Table 2). In contrast, the lowest dry weights in the control and heat stress treatments were observed for Early Wonder and Jagour. Jagour also produced low dry weight under disease stress. When heat and disease stresses were combined, the genotype VI005856 again produced the highest dry weight as did a different genotype: LA0373. Jagour once again produced low dry weight under the combined stresses.

The plant dry weight and the fruit set inhibition of various genotypes are presented in Fig. 3. The genotype LA 3847 had low fruit inhibition, produced the highest quantity of fruit but did not have the highest dry weight per plant indicating a high harvest index.

\section{Correlations among key traits}

Plant dry weight under controlled conditions (PDWC) was significantly correlated with dry weight (PDW) under disease and heat stress conditions (Table 3). However, the relationship between fruit set inhibition (FSI) and the disease susceptibility index (DSI) was statistically non-significant (Fig. 5).

\section{Discussion}

The effect of heat stress was evident on all traits assessed (IPP, FSR, FPP, FFW, DSI, and dry weight); however, the effect varied and genotype dependent. Flower to fruit ratio or fruit set inhibition (FSI) is a reliable parameter that can be used to assess the heat tolerance of tomato genotypes (Wahid et al., 2007). The genotype LA 3847 had minimum FSI and the highest fruit yield under heat and disease stress (Fig. 3). In contrast, LA 4252 and Jagour had the highest FSI score. The fruit setting of the three wild types; LA 0373, LA 0716, and LA 1930, was very poor under the control and combined (disease + heat) stress conditions. Nevertheless, the wild types did produce intermediate levels of dry matter in all treatments (Table 2). The poor fruit setting of these genotypes is likely an artifact of their poor adaptability. 
Table 1. Analysis of variance for various traits under different treatments.

\begin{tabular}{|c|c|c|c|c|c|c|c|c|c|}
\hline TRAIT & SOV & DF & MS & PROB & TRAIT & SOV & $\begin{array}{l}\mathrm{D} \\
\mathrm{F}\end{array}$ & MS & PROB \\
\hline \multirow{7}{*}{ IPP } & Entry & 9 & 7150.4 & $<.001$ & \multirow{7}{*}{ DSI } & Entry & 9 & 5063.8 & $<.001$ \\
\hline & Disease & 1 & 1650.2 & $<.001$ & & Disease & 1 & 70688.8 & $<.001$ \\
\hline & Heat & 1 & 378.1 & $<.001$ & & Heat & 1 & 470.1 & $<.001$ \\
\hline & Entry*Disease & 9 & 122.6 & $<.001$ & & Entry*Disease & 9 & 5063.8 & $<.001$ \\
\hline & Entry*Heat & 9 & 197.8 & $<.001$ & & Entry*Heat & 9 & 24.5 & $\begin{array}{l}0.232 \\
<\end{array}$ \\
\hline & \multirow{2}{*}{$\begin{array}{l}\text { Disease*Heat } \\
\text { Entry*Disease*Hea } \\
\mathrm{t}\end{array}$} & 1 & 37.4 & $<.001$ & & Disease*Heat & 1 & 470.1 & $<.001$ \\
\hline & & 9 & 24.9 & $<.001$ & & Entry*Disease*Heat & 9 & 24.5 & $\begin{array}{l}0.232 \\
<\end{array}$ \\
\hline \multirow{7}{*}{$\begin{array}{l}\text { FS Inhib } \\
(\%)\end{array}$} & Entry & 7 & 299.22 & $<.001$ & \multirow{7}{*}{ FFW (g) } & Entry & 9 & 351468 & $<.001$ \\
\hline & Disease & 1 & 1720.92 & $<.001$ & & Disease & 1 & $\begin{array}{l}131082 \\
2\end{array}$ & $<.001$ \\
\hline & Heat & 1 & $\begin{array}{l}152273.8 \\
0\end{array}$ & $<.001$ & & Heat & 1 & $\begin{array}{l}503970 \\
0\end{array}$ & $<.001$ \\
\hline & Entry*Disease & 7 & 98.15 & $0.013<$ & & Entry*Disease & 9 & 372648 & $<.001$ \\
\hline & Entry*Heat & 7 & 491.11 & $<.001$ & & Entry*Heat & 9 & 547214 & $<.001$ \\
\hline & Disease*Heat & 1 & 2444.37 & $<.001$ & & Disease*Heat & 1 & 158742 & $<.001$ \\
\hline & $\begin{array}{l}\text { Entry*Disease*Hea } \\
\mathrm{t}\end{array}$ & 7 & 159.19 & $<.001$ & & Entry*Disease*Heat & 7 & 26276 & $<.001$ \\
\hline \multirow{7}{*}{ FPP } & Entry & 9 & 16220.56 & $<.001$ & \multirow{7}{*}{ PDW (g) } & Entry & 9 & 20854.4 & $<.001$ \\
\hline & Disease & 1 & 2861.48 & $<.001$ & & Disease & 1 & 93593.4 & $<.001$ \\
\hline & Heat & 1 & 42583.54 & $<.001$ & & Heat & 1 & 7015.1 & $<.001$ \\
\hline & Entry*Disease & 9 & 326.92 & $<.001$ & & Entry*Disease & 1 & 3926.8 & $<.001$ \\
\hline & Entre*Heat & 9 & 13503.24 & $<.001$ & & Entry*Heat & 9 & 303.1 & $<.001$ \\
\hline & Disease*Heat & 1 & 896.62 & $<.001$ & & Dis*Heat & 1 & 9178.8 & $<.001$ \\
\hline & $\begin{array}{l}\text { Entry*Disease*Hea } \\
\mathrm{t}\end{array}$ & 7 & 69.59 & $<.001$ & & Entry*Dis*Heat & 9 & 280.1 & $<.001$ \\
\hline
\end{tabular}

The fruit set inhibition and fruit fresh weight, considered together, better characterizes genotype response to disease and heat stress. The significant observed variation among genotypes for fruit set inhibition and fresh fruit weight suggests that sufficient genetic variation exists to improve tomato for both disease resistance and heat stress. These results support the earlier reports of Lindhout et al., (1991) and Foolad and Lin, (2000) who concluded that variation in temperature responses and growth rates exists in wild tomato. The non-significant correlation between fruit set inhibition and the disease susceptibility index supports the notion that both traits can be simultaneously and independently improved through breeding. Temperature is an important environmental factor in greenhouses and regulates many aspects of growth and development in plants. However, excessive temperatures can lead to inhibition of inflorescences and reduced fruit setting. High temperature retards flower and fruit development by impacting pollen and ovule meiosis, the position of the stigma, pollen productivity, pollen germination, ovule growth, fertilization, embryo growth and ultimately fruit set (Peet et al., 1997; Ruan et al., 2010).

The DSI under both controlled conditions and heat stress was strongly correlated (Fig. 2) indicating that cultivars tolerant to Fusarium wilt under heat stress maintain their resistance under a range of temperatures.

Sakata et al., (2000) suggested that reproductive tissue was more vulnerable to higher temperatures $\left(32 / 26^{\circ} \mathrm{C}\right.$ day and night) than vegetative tissue. Tomato is sensitive to temperature and variable response to high temperature has been recorded (Picken, 1984). In the current study, floral structures were observed to be susceptible to heat stress. The fruit setting stage was very sensitive to high-temperature and flowers tended to drop because of the impact of high temperature on fertilization, embryo growth and fruit set. These findings are consistent with Peet et al., (1997) who reported that heat stress reduced flower and fruit development.

The highest plant dry weight under both temperature treatments was observed for the genotype VI005856 (Table 2). However, fruit set inhibition under heat and disease stress was very high $(95.8 \%)$, thus this genotype produced low fresh fruit weight. Similar genotype responses to hightemperature were noted earlier by Abdul-Baki, (1991).

Greater fruit inhibition occurred under heat stress compared to disease stress (Table 2). The mean fruit set inhibition due to disease stress was $53.3 \%$ compared to $89.8 \%$ under heat stress. The combined effect of disease and heat stress was similar to heat stress alone at $88.1 \%$ mean fruit set inhibition. It was clear that high temperature was the most limiting factor on fruit setting and greater than the effect of Fusarium wilt alone. Temperatures above the optimal range disrupt sugar metabolism and proline translocation during the narrow window of male reproductive development and could also cause developmental abnormalities in male and female reproductive tissues, thereby reducing the supply of photosynthetic assimilate and growth regulators in sink tissues (Kinet and Peet, 1997). Heat stress clearly reduces pollen viability and the development of fruit and seed (Sato et al., 2000).

The impacts of elevated temperatures are complex in tomato and it is difficult to determine the critical maximum 


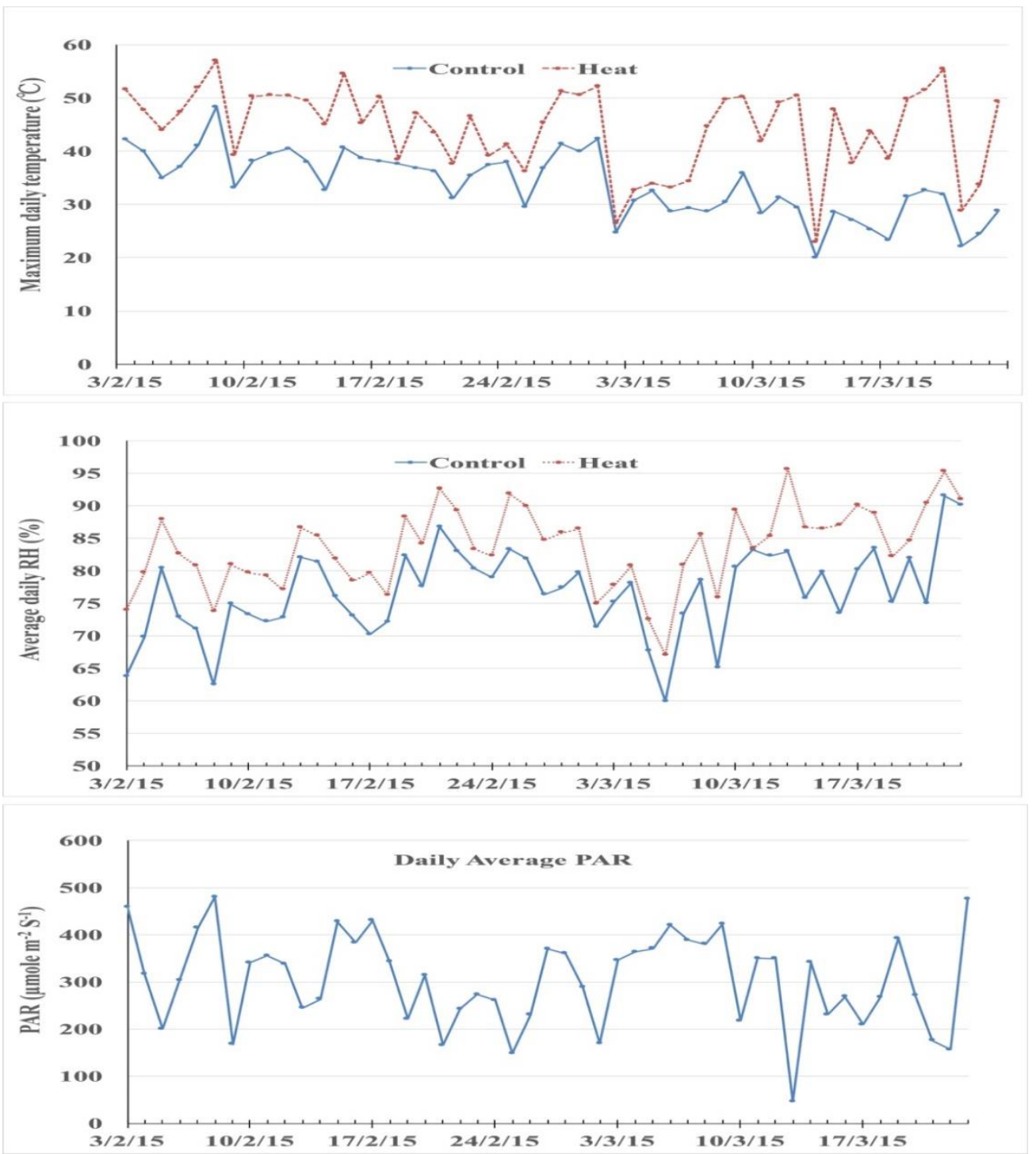

Fig 1. Maximum daily temperature, photosynthetically active radiation (PAR), and relative humidity (RH) during the growth season in the tunnel house.

temperature during reproductive development. Lovatt et al., (1998) concluded that the growth of sensitive cultivars was reduced when mean daily temperatures exceeded $25^{\circ} \mathrm{C}$, whereas more heat tolerant genotypes were impacted above $32^{\circ} \mathrm{C}$. The greater severity of combined disease and heat stress observed in the current study is likely a function of inhibited plant defense mechanisms. Kuuan et al., (2001) reported that heat shock inhibited the defense mechanisms of plants and Landa et al., (2006) observed that chickpea became more susceptible to Fusarium wilt under heat stress. Under marginal conditions fruit may set without adequate pollination, however the internal fruit segments often contain few seeds and the fruit can be flat sided and puffy. Irregular pollination can also cause the fruit disorder known as cat face (Masarirambi et al., 2009). Fruit setting in the current study was reduced when temperatures exceeded the optimum temperature for fruit set. Others observed that mean daily temperature increases produced significant decreases in relative seediness, percentage fruit set and total number and weight of fruit per plant (Kumar et al., 2012; Ruan et al., 2010; Peet et al., 1997; Rudich et al., 1977; and Sato et al., 2006).

The current study focused on the interaction between heat and disease treatments. The interaction between genotypes and heat treatments was significant indicating that genetic improvement of tomato under heat stress is possible.

Likewise the significant interaction between genotypes and disease indicates that disease resistance can be improved. The significant three-way interactions between genotypes, heat and disease treatments for all traits suggests that genetic improvement for tolerance to both stresses, although possible, will be difficult. Nevertheless, combining heat and disease stress tolerance will increase fruit set and yield.

\section{Materials and methods}

\section{Plant material and the growing conditions}

Ten accessions of tomato including one accession from each of the wild species $S$. pimpinellifolium, $S$. pennelli and $S$. chilense and seven of S. lycopersicum, were selected on the basis of their tolerance to Fusarium solani (Isolate ID: BRIP 28072) (Table 1). The seed was sourced from the Tomato Genetic Resource Center (UC Davis, USA), the World Vegetable Research and Development Center (AVRDC, Taiwan), the Vegetable Research Institute (VRI, Pakistan) and the Diggers Club (Australia). The experiments were established from cuttings taken from plants raised in the 
Table 2. Comparison of genotypic means and derived values under different treatments.

\begin{tabular}{|c|c|c|c|c|c|c|c|c|c|c|c|c|c|}
\hline Trait/Genotype & IPPI & IPPI & IPPI & $\begin{array}{l}\mathrm{FS} \\
\text { ratio }\end{array}$ & $\begin{array}{l}\text { FS } \\
\text { Inhib } \\
(\%)\end{array}$ & $\begin{array}{l}\text { FS } \\
\text { Inhib } \\
(\%)\end{array}$ & $\begin{array}{l}\text { FS Inhib } \\
(\%)\end{array}$ & DSI & DSI & PDW(g) & $\begin{array}{l}\text { PDW } \\
\text { (g) }\end{array}$ & $\begin{array}{l}\text { PDW } \\
\text { (g) }\end{array}$ & PDW (g) \\
\hline & Heat & Disease & (Dis+Heat) & Control & Heat & (Disease) & (Dis+Heat) & (Control) & (Heat) & (Control) & (Heat) & (Disease) & (Dis+Heat) \\
\hline A Paste & $14.33^{\mathrm{E}}$ & $14.67^{\mathrm{C}}$ & $14.67^{\mathrm{C}}$ & $40.56^{\mathrm{C}}$ & $91.88^{\mathrm{AB}}$ & $49.58^{\mathrm{C}}$ & $93.65^{\mathrm{AB}}$ & $8.33^{\mathrm{E}}$ & $16.67^{\mathrm{C}}$ & $108.83^{\mathrm{E}}$ & $126.97^{\mathrm{G}}$ & $105.53^{\mathrm{C}}$ & $104.33^{\mathrm{C}}$ \\
\hline BB Steak & $27.67^{\mathrm{C}}$ & $2.67^{\mathrm{E}}$ & $2.67^{\mathrm{D}}$ & $32.11^{\mathrm{D}}$ & $86.89^{\mathrm{BC}}$ & $44.82^{\mathrm{C}}$ & $68.01^{\mathrm{C}}$ & $83.33^{\mathrm{C}}$ & $100.00^{\mathrm{A}}$ & $151.40^{\mathrm{B}}$ & $198.20^{\mathrm{C}}$ & $66.13^{\mathrm{E}}$ & $62.30^{\mathrm{E}}$ \\
\hline E Wonder & $10.33^{\mathrm{F}}$ & $12.67^{\mathrm{D}}$ & $12.67^{\mathrm{C}}$ & $26.52^{\mathrm{E}}$ & $83.97^{\mathrm{BC}}$ & $51.25^{\mathrm{BC}}$ & $86.45^{\mathrm{B}}$ & $33.33^{\mathrm{D}}$ & $45.83^{\mathrm{B}}$ & $69.70^{\mathrm{H}}$ & $80.37^{\mathrm{I}}$ & $53.17^{\mathrm{F}}$ & $53.47^{\mathrm{EF}}$ \\
\hline Jagour & $10.33^{\mathrm{F}}$ & $3.33^{\mathrm{E}}$ & $3.33^{\mathrm{D}}$ & $23.99^{\mathrm{F}}$ & $95.83^{\mathrm{A}}$ & $63.89^{\mathrm{A}}$ & $100.00^{\mathrm{A}}$ & $91.67^{\mathrm{B}}$ & $100.00^{\mathrm{A}}$ & $77.97^{\mathrm{G}}$ & $103.53^{\mathrm{H}}$ & $31.33^{\mathrm{G}}$ & $21.00^{\mathrm{G}}$ \\
\hline LA $0373^{+}$ & $70.67^{\mathrm{B}}$ & $64.67^{\mathrm{B}}$ & $64.67^{\mathrm{B}}$ & $52.63^{\mathrm{A}}$ & $95.02^{\mathrm{A}}$ & $50.14^{\mathrm{C}}$ & $95.32^{\mathrm{A}}$ & $4.17^{\mathrm{E}}$ & $4.17^{\mathrm{D}}$ & $143.37^{\mathrm{C}}$ & $188.20^{\mathrm{D}}$ & $134.53^{\mathrm{B}}$ & $150.03^{\mathrm{A}}$ \\
\hline LA $0716^{++}$ & $3.33^{\mathrm{G}}$ & $2.33^{\mathrm{E}}$ & $2.33^{\mathrm{D}}$ & $0.00^{\mathrm{G}}$ & $*$ & $*$ & $*$ & $8.33^{\mathrm{E}}$ & $12.50^{\mathrm{CD}}$ & $102.00^{\mathrm{F}}$ & $123.77^{\mathrm{G}}$ & $88.57^{\mathrm{D}}$ & $80.47^{\mathrm{D}}$ \\
\hline LA $1930^{+++}$ & $77.00^{\mathrm{A}}$ & $73.00^{\mathrm{A}}$ & $73.00^{\mathrm{A}}$ & $0.00^{\mathrm{G}}$ & $*$ & * & $*$ & $4.17^{\mathrm{E}}$ & $8.33^{\mathrm{D}}$ & $151.43^{\mathrm{B}}$ & $205.87^{\mathrm{B}}$ & $147.47^{\mathrm{A}}$ & $138.50^{\mathrm{B}}$ \\
\hline LA 3847 & $14.00^{\mathrm{E}}$ & $4.33^{\mathrm{E}}$ & $4.33^{\mathrm{D}}$ & $41.05^{\mathrm{C}}$ & $75.07^{\mathrm{D}}$ & $47.98^{\mathrm{C}}$ & $65.74^{\mathrm{C}}$ & $83.33^{\mathrm{C}}$ & $95.83^{\mathrm{A}}$ & $121.67^{\mathrm{D}}$ & $153.87^{\mathrm{E}}$ & $48.70^{\mathrm{F}}$ & $48.43^{\mathrm{F}}$ \\
\hline LA 4252 & $11.00^{\mathrm{F}}$ & $2.33^{\mathrm{E}}$ & $2.33^{\mathrm{D}}$ & $47.84^{\mathrm{B}}$ & $96.60^{\mathrm{A}}$ & $64.54^{\mathrm{A}}$ & $100.00^{\mathrm{A}}$ & $100.00^{\mathrm{A}}$ & $100.00^{\mathrm{A}}$ & $123.20^{\mathrm{D}}$ & $134.37^{\mathrm{F}}$ & $27.00^{\mathrm{G}}$ & $24.93^{\mathrm{G}}$ \\
\hline VI005856 & $19.00^{\mathrm{D}}$ & $14.67^{\mathrm{C}}$ & $14.67^{\mathrm{C}}$ & $41.39^{\mathrm{C}}$ & $92.71^{\mathrm{AB}}$ & $54.52^{\mathrm{B}}$ & $95.81^{\mathrm{AB}}$ & $29.17^{\mathrm{D}}$ & $41.67^{\mathrm{B}}$ & $182.90^{\mathrm{A}}$ & $245.17^{\mathrm{A}}$ & $146.40^{\mathrm{A}}$ & $143.37^{\mathrm{AB}}$ \\
\hline Mean & 25.77 & 19.47 & 19.47 & 30.61 & 89.75 & 53.34 & 88.12 & 44.58 & 52.5 & 123.25 & 156.03 & 84.88 & 82.68 \\
\hline $\operatorname{LSD}_{(.05)}$ & 1.91 & 1.91 & 2.7 & 1.91 & 6.84 & 6.84 & 9.67 & 4.92 & 6.95 & 4.5 & 6.37 & 6.37 & 9.01 \\
\hline $\mathrm{CV}(\%)$ & 6.8 & 6.8 & 6.8 & 14.7 & 12.1 & 12.1 & 12.1 & 17.6 & 17.6 & 5 & 5 & 5 & 5 \\
\hline
\end{tabular}

${ }^{+}$S. pimpinellifolium, ${ }^{++}$S. Pennelli, ${ }^{+++}$S. chilense, $*$ no fruit setting.

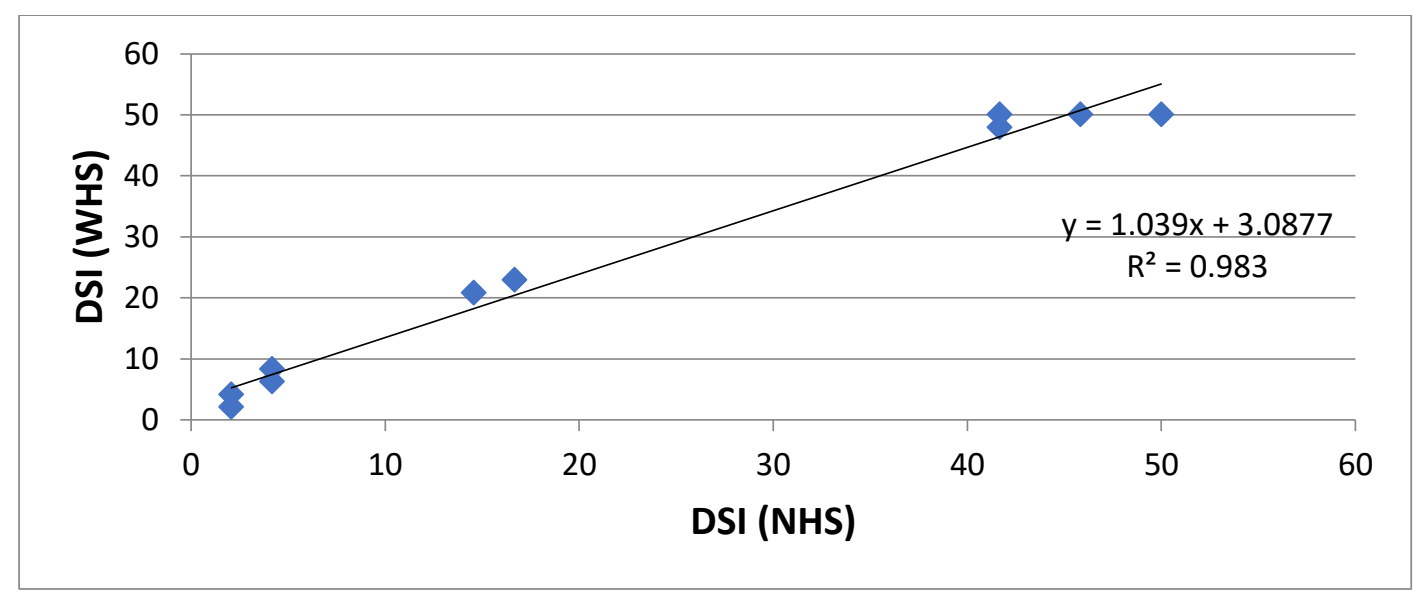

Fig 2. Relationship between disease severity index under both control [DSI (NHS)] and heat stress treatments [DSI (WHS)]

Table 3. The correlations matrix among various traits under disease and heat stress.

\begin{tabular}{lrrr}
\hline & $P D W C$ & $P D W($ Dis + Heat $)$ & F Inhib (Dis + Heat $)$ \\
\hline PDWC & & & \\
PDW (Dis+Heat) & $\mathbf{0 . 9 3}$ & & \\
F Inhib (Dis + Heat) & 0.05 & 0.18 & -0.40 \\
FFW (Dis+Heat) & 0.29 & 0.43 & \\
\hline The bold face value is significant at $\mathrm{p} \leq 0.05$ & & \\
\hline
\end{tabular}

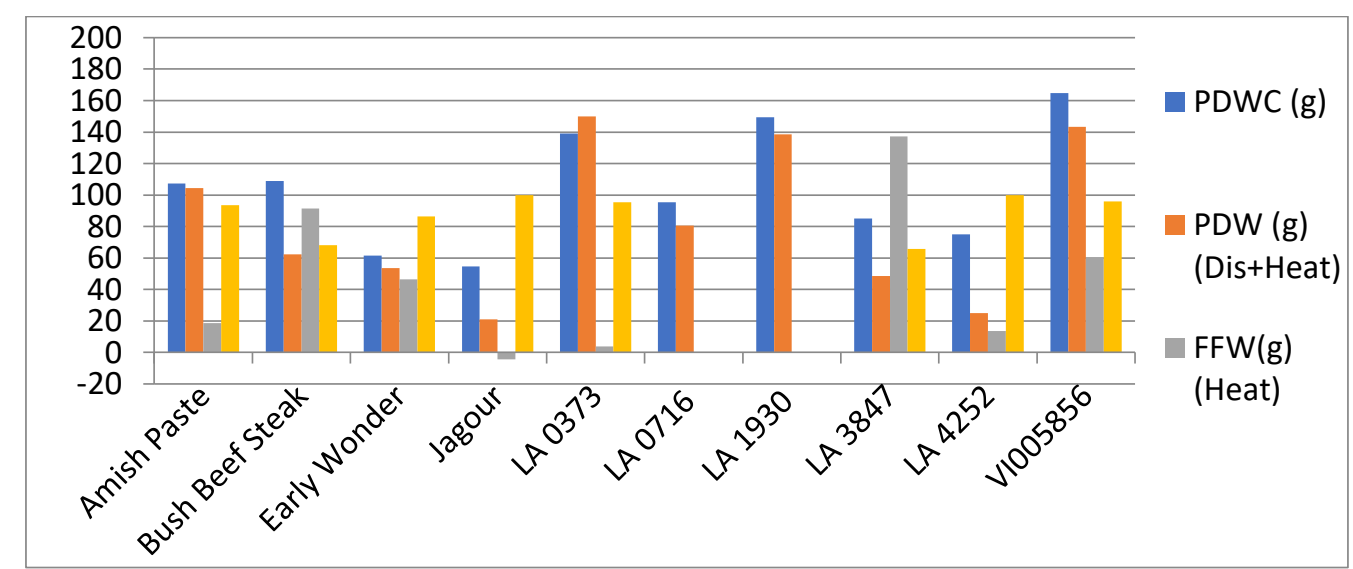

Fig 3. Trait expression of various genotypes. PDWC (plant dry weight under control), PDW (plant dry weight under disease and heat stress), FFW (fresh fruit weight under disease and heat stress), F Inhib (fruit inhibition under disease and heat stress). 


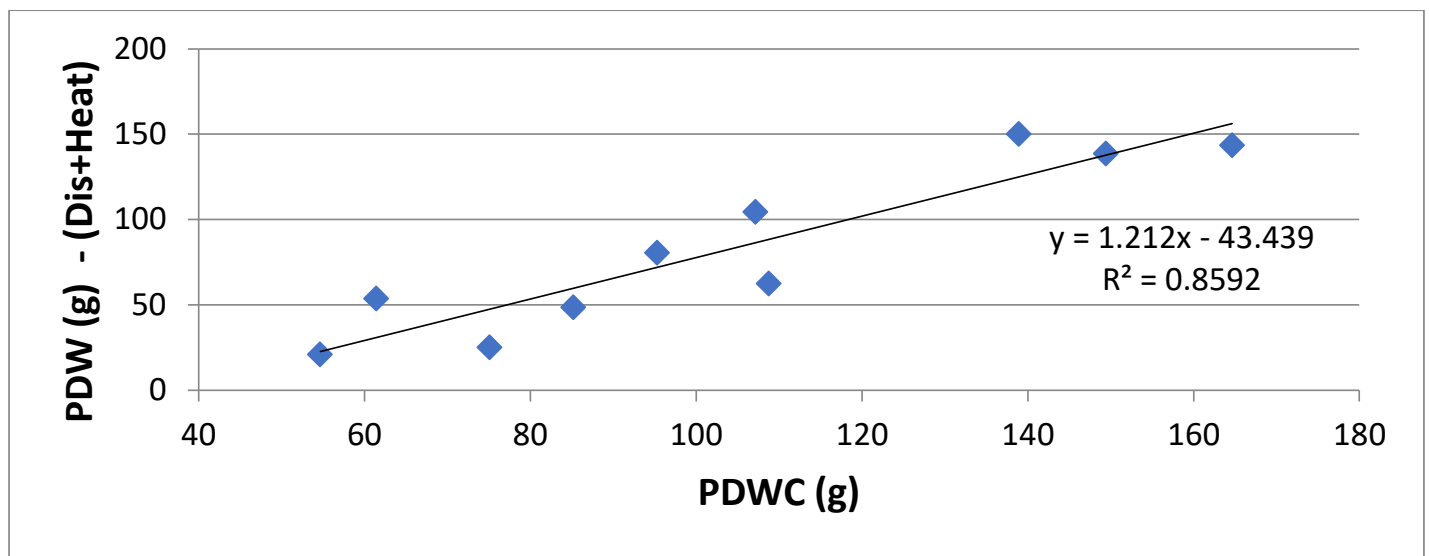

Fig 4. Relationship between plant dry weight under control (PDWC) and combined treatments [PDW (Dis+Heat)].

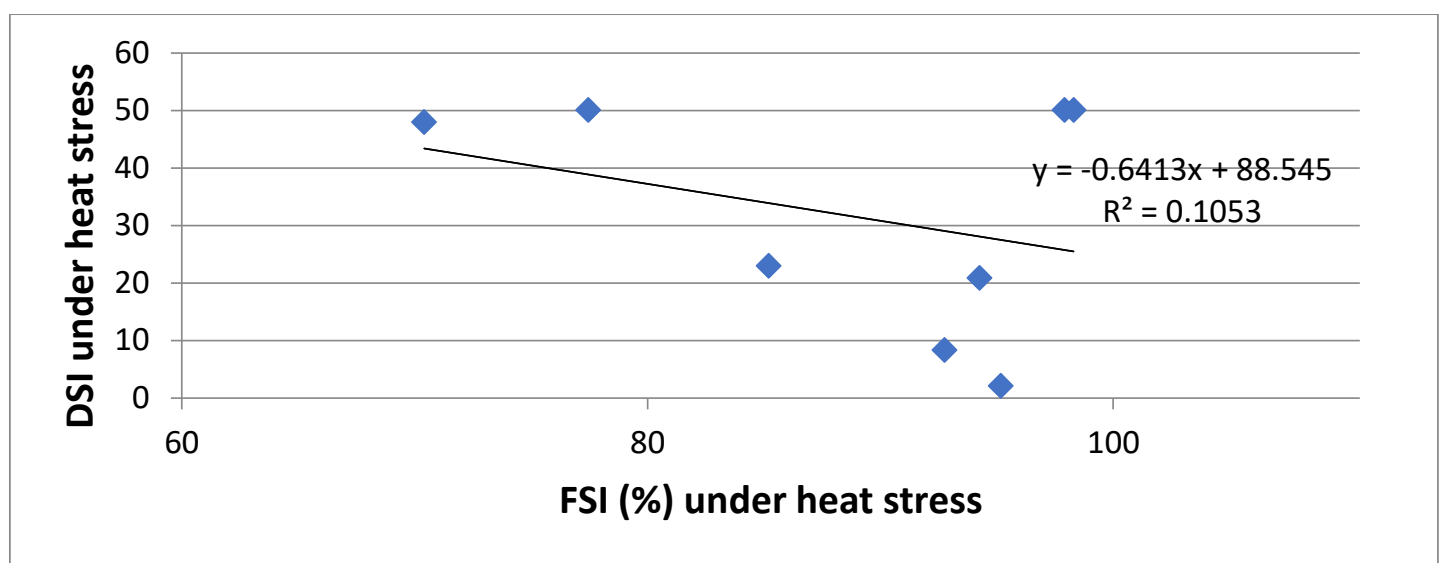

Fig 5. Relationship between fruit set inhibition (FSI) and disease susceptibility index (DSI) under heat stress conditions.

greenhouse from the original seed. Plants were grown in 10L capacity commercial grade cocopeat bags in a hydroponic tunnel house at The University of Sydney Plant Breeding Institute (Latitude: -34.02, Longitude: 150.67, Altitude: 87m) during summer, 2014-2015.

The experiment was comprised of ten tomato genotypes, two levels of disease severity and two levels of heat stress with three replications of each genotype per treatment. Two temperature treatments were created in two separate sections of the tunnel-house. The plants were fertigated using a commercial fertilizer recipe. The high temperature section accumulated heat from the sun and temperatures on most days during the growing season exceeded $40^{\circ} \mathrm{C}$. Ventilation was closely monitored on hot days to avoid excessive heat stress in the hot section.

The temperature, relative humidity and photosynthetically active radiation (PAR) in the tunnel house was recorded using a CR200X data logger (Campbell Scientific Australia, Townsville, Qld, Australia) (Fig 1). Management protocols applied in both sections of the tunnel house were identical except for the variation in temperature treatment. The plant data were recorded at maturity.

\section{Source of the fungal isolate and preparation of inoculum}

A pure $F$. solani isolate was obtained from the plant pathology herbarium - Biosecurity Queensland Australia.

Fungal inoculum was cultured on potato dextrose agar (PDA) for 10 days in petri dishes. Inoculum of Fusarium solani, the causative organism of Fusarium wilt of tomato ( $S$. lycopersicum) was prepared in petri dishes by culturing spores on potato dextrose agar (PDA) for a period of 10 days. The microconidial suspension was made by pouring $1 \mathrm{ml}$ of distilled water into the petri dish to loosen spores for scrapping and removal. The $1 \mathrm{~m} 1$ volume of suspension was adjusted to $20 \mathrm{ml}$ in sterile bottles and subsequently shaken using a rotary shaker to remove the spores from the mycelia to produce $10^{6}$ spore $/ \mathrm{ml}$ concentration.

\section{Measurement of disease severity}

The disease incidence was measured 60 days after pathogen inoculation. The disease severity was recorded on a 0-4 scale as described by Weitang et al., (2004); where zero represents no infection and four denotes complete infection. Three replications in a randomized complete block design (RCBD) were maintained for each of the two disease treatments. The $0-4$ scale of the disease severity was classified as follows:

0 - No infection.

1 - Slight infection, which is about $25 \%$ of complete infection, one or two leaves turned yellow.

2 - Moderate infection, two or three branches turned yellow, $50 \%$ of leaves wilted.

3 - Extensive infection, all the leaves turned yellow, $75 \%$ of leaves wilted and growth is inhibited.

4 - Complete infection, the leaves of the whole plant turned yellow, $100 \%$ of leaves wilted, and the plants dead.

The disease incidence percentage was determined using the formula (Weitang et al., 2004): 
Disease severity $(\%)=[\Sigma($ No. infected plants $\times$ their infected degree) / (total examined/tested plants $\times$ upper infected degree) $] \times 100$.

\section{Phenotyping}

All ten tomato accessions were phenotyped for response to high-temperature in the summer of 2014-2015. The accessions were evaluated for the following traits: number of inflorescence per plant (IPP), fruit set ratio (FSR), number of fruits per plant (FPP), fruit fresh weight (FFW), disease susceptibility index (DSI), and plant dry weight (PDW). The fruit set inhibition was calculated using the formula:

Fruit set inhibition $(\%)=100-$ $\left[\frac{\text { Total number of fruites }}{\text { Total number of flowers }}\right]$ X100

\section{Statistical analysis}

The analysis of variance was conducted using the general treatment structure for randomized complete block designs in the GenStat (v 18.0) statistical software package. The components of variance were considered significant at $\mathrm{P} \leq$ 0.05 . The genotypes were compared using LSD $(\mathrm{P}<0.05)$ scores for individual traits. Correlations among various traits were calculated using the Excel Data Analysis Package (2010).

\section{Conclusion}

Use of disease resistant cultivars is a practical, cost-efficient, and environmentally safe way of managing Fusarium wilt in tomatoes. This study concluded that: Genetic variation exists in the tomato germplasm for tolerance to disease and heat stress and new and diverse sources of germplasm can be used to develop disease and heat tolerant cultivars. The genotype LA 3847 was well adapted to heat and Fusarium wilt stress. Fruit set inhibition is a reliable parameter for assessing tomato response to heat stress. Under heat and disease stress, genotypes with low fruit set inhibition and high fruit yield are desirable. The lowest fruit set inhibition was recorded for LA 3847. Earlier findings that Fusarium wilt increases with increasing temperature were confirmed. However a strong correlation between the disease severity index under optimal and heat stress conditions supports the notion that cultivars bred in optimal conditions could be adapted to heat stress and vice versa.

\section{Acknowledgments}

Authors acknowledge the valuable support of the staff and students of the Plant Breeding Institute, The University of Sydney in the completion of this study. Authors also thankfully acknowledge the contributions made by Biosecurity Queensland with providing the disease inoculum, TGRC, UC Davis for providing the tomato germplasm, and ACIAR vegetables project HORT/2012/002 for the research support.

\section{References}

Abdel-Monaim MF (2012) Induced systemic resistance in tomato plants against Fusarium wilt disease. Int Res J Microbiol. 3:14-23.

Abdul-Baki AA (1991) Tolerance of tomato cultivars and selected germplasm to heat stress. J Amer Soc Hort Sci. 116:1113-1116.

Abu Bakar AI, Nur Ain Izzati MZ, Umi Kalsom Y (2013) Diversity of Fusarium species associated with post-harvest fruit rot disease of tomato. Sains Malays. 42:911-920.

Bai Y, Lindhout P (2007) Domestication and breeding of tomatoes: what have we gained and what can we gain in the future? Ann Bot.100:1085-1094.

Bogner CW, Kariuki GM, Elashry A, Sichtermann G, Buch AK, Mishra B, Thines M, Grundler FM, Schouten A (2016) Fungal root endophytes of tomato from Kenya and their nematode bio-control potential. Mycol Prog. 15:1-17.

Bohnert HJ, Donald EN, Richard GJ (1995) Adaptations to environmental stresses. Plant Cell. 7:1099-1111.

Burgess LW, Summerell BA, Bullock S, Gott KP, Bakhous D ( 1994) Laboratory manual for fusarium research. Fusarium Research Laboratory, Department of Crop Science, University of Sydney and Royal Botanic Gardens, $133 \mathrm{pp}$.

Chen TH, Murata N (2002) Enhancement of tolerance of abiotic stress by metabolic engineering of betaines and other compatible solutes. Curr Opin Plant Biol. 5(3):250257.

Esquinas-Alcazar JT (1981) Genetic resources of tomatoes and wild relatives: A global report. IBPGR. Italy.

Fang X, Phillips D, Li H, Sivasithamparam K, Barbetti MJ (2011) Comparisons of virulence of pathogens associated with crown and root diseases of strawberry in Western Australia with special reference to the effect of temperature. Sci Hort. 131:39-48.

Foolad MR, Lin GY (2000) Relationship between cold tolerance during seed germination and vegetative growth in gene discovery. Genome. 43:803-813.

Hedhly A, Jose IH, Maria H (2009) Global warming and sexual plant reproduction. Trends Plant Sci.. 14:30-36.

Kinet JM, Peet MM (1997) Tomato. In: The Physiology of Vegetable Crops (ed. H.C. Wien), pp. 207-258. CAB International, Wallingford, UK.

Kumar SV, Lucyshyn D, Jaeger KE, Alós E, Alvey E, Harberd NP, Wigge PA (2012) Transcription factor PIF4 controls the thermosensory activation of flowering. Nature. 484(7393):242-5.

Kuo CG, Chen BW, Chou MH, Tsai CL, Tsay TS (1979) Tomato fruit-set at high temperatures. In Proceedings of the 1st International Symposium on Tropical Tomato, 23-27 October 1978 at Shanhua, Tainan 741, Taiwan, Republic of China, pp. 94-109. AVRDC. No. 78-59.

Kuuan KG, Okole B, Borman L ( 2001) Protection of phenylproponoid metabolism by prior heat treatment in Lycopersicon esculentum exposed to Relstonia solanacearum. Plant Physiol Biochem. 39: 871-880.

Landa BB, Navas-Cortés JA, Jiménez-Gasco MM, Katan J, Retig B, Jiménez-Díaz RM (2006) Temperature response of chickpea cultivars to races of Fusarium oxysporum $f$. sp. ciceris, causal agent of fusarium wilt. Plant Dis. 90:365374.

Leslie JF, Brett A, Summerell, Suzanne B (2006) The Fusarium laboratory manual. Vol. 2. No. 10. Ames, IA, USA: Blackwell Publication.

Lindhout P, Pet G, Jansen R, Jansen H (1991) Genetic differences in growth within and between Lycopersicon species. Euphytica. 57:259-265.

Lohar D, Peat W (1998) Floral characteristics of heat-tolerant 
and heat-sensitive tomato (Lycopersicon esculentum Mill.) cultivars at high temperature. Sci Hort. 73(1):53-60.

Lovatt J, Fullelove G, Wright R, Meurant N, Barnes J, O'Brien R (1998) Tomato information kit. QDPI. Australia.

Masarirambi MT, Mhazo N, Oseni T, Shongwe V (2009) Common physiological disorders of tomato (Lycopersicon esculentum) fruit found in Swaziland. J Agric Soc Sci.5:123-127.

Matuo T, William CS (1973) Use of morphology and mating populations in the identification of formae speciales in Fusarium solani. Phytopathology. 63:562-565.

Peet MM, Willits DH, Gardner R (1997) Response of ovule development and post-pollen production processes in malesterile tomatoes to chronic, sub-acute high temperature stress. J Exp Bot. 48:101-112.

Peet MM, Sato S, Gardner RG (1998) Comparing heat stress effects on male-fertile and male-sterile tomatoes. Plant Cell Environ. 21:225-231.

Pék Z, Helyes L (2004) The effect of daily temperature on truss flowering rate of tomato. J Sci Food Agr. 84:16711674.

Picken A (1984) A review of pollination and fruit set in the tomato (Lycopersicon esculentum Mill.). J Hortic Sci. 59:1-13.

Rhodes D, Hanson A (1993) Quaternary ammonium and tertiary sulfonium compounds in higher plants. Annu Rev Plant Biol. 44:357-384.

Robert PL, Fravel DR (2002) Effects of varying environmental conditions on biological control of fusarium wilt of tomato by nonpathogenic fusarium spp. Phytopathology. 92:1160-1166.

Rojo FG (2007) Biological control by Trichoderma species of Fusarium solani causing peanut brown root rot under field conditions. Crop Prot. 26:549-555.

Ruan YL, Jin Y, Li GJ, Yang YJ, Boyer JS (2010) Sugar input, metabolism and signaling mediated by invertase: Roles in development, yield potential and response to drought and heat. Mol Plant. 3:942-955.

Rudich J, Zamski E, Regev Y (1977) Genotypic variation for sensitivity to high temperature in the tomato: Pollination and fruit set. Bot Gaz. 138:448-452.
Saad MM (2006) Destruction of Rhizoctonia solani and Phytophthora capsici causing tomato root-rot by Pseudomonas fluorescens lytic enzymes. Res J Agric Biol Sci. 2:274-281.

Sakata T, Takahashi H, Nishiyama I, Higashitani A (2000) Effects of high temperature on the development of pollen mother cells and microspores in barley (Hordeum vulgare L.). J Plant Res. 113(4):395-402.

Saseetharan M, Huda N, Zakaria L (2014) Occurrence of fusarium spp. on vegetable crops and assessment of their pathogenicity. Pertanika J Trop Agric Sci. 37: 445-455.

Sato S, Kamiyama M, Iwata T, Makita N, Furukawa H, Ikeda $\mathrm{H}$ (2006) Moderate increase of mean daily temperature adversely affects fruit set of Lycopersicon esculentum by disrupting specific physiological processes in male reproductive development. Ann Bot. 97:731-738.

Sato S, Peet MM, Thomas JF (2000) Physiological factors limit fruit set of tomato (Lycopersicon esculentum Mill.) under chronic, mild heat stress. Plant Cell Environ. 23:719726.

Scott JC, Gordon TR, Shaw DV, Koike ST (2010) Effect of temperature on severity of fusarium wilt of lettuce caused by Fusarium oxysporum f. sp. lactucae. Plant Dis. 94(1):137.

Singh AK, Kamal S (2012) Chemical control of wilt in tomato (Lycopersicon esculentum L.). Int J Horticulture. 2:5-6.

Tu JC (1994) Effects of soil compaction, temperature, and moisture on the development of the fusarium root rot complex of pea in southwestern Ontario. Phytoprotection. 75(3):125-31.

Villareal RL, Lai SH, Wong SH (1978) Screening for heat tolerance in the genus Lycopersicon [Tomatoes, cultivars]. HortScience. (USA).

Wahid A, Gelani S, Ashraf A, Foolad M (2007) Heat tolerance in plants: an overview. Environ Exp Bot. 61:199223.

Weitang S, Ligang Z, Chengzong Y, Xiaodong C, Liqun Z, Xili L (2004) Tomato fusarium wilt and its chemical control strategies in a hydroponic system. Crop Prot. 23:120-123.

Woloshuk CP, ShimWB (2013) Aflatoxins, fumonisins, and trichothecenes: a convergence of knowledge. FEMS Microbiol Rev. 37:94-109. 